Research, part of a Special Feature on A Systems Approach for Sustainable Development in Coastal Zones

\title{
The impact of water quality changes on the socio-economic system of the Guadiana Estuary: an assessment of management options
}

\author{
${\underline{M^{a} \text { Helena E. Guimarães }}}^{1}, \underline{\text { André Mascarenhas }}^{2}{ }^{\text {Carlos Sousa }}{ }^{3}, \underline{\text { Tomasz Boski }}^{3}{ }^{\text {, and Tomaz Ponce Dentinho }}{ }^{4}$
}

\begin{abstract}
Tourism related to bathing has a growing economic importance in the Guadiana Estuary in southern Spain and Portugal. Polls of local public opinion showed an awareness of potential and current threats to the aquatic environment posed by regulation of river flow and untreated/poorly-treated urban sewage discharge. Because of this strong concern for water quality, it was selected as the policy issue for our application of the Systems Approach Framework (SAF). We developed an integrated simulation model of the Guadiana estuarine system in which the ecological system and socioeconomic components are linked by means of beach eco-label (Blue Flag Award) through its dependence on fecal bacterial thresholds. We quantified the socioeconomic impacts of water quality through an Economic Base Model that is used to portray the effect of increasing employment on resident population as a result of change in coastal water quality. A Cost-Benefit Analysis provides monetary indicators for scenario evaluation. It includes a monetary valuation of changes in water quality on human welfare using a Contingent Valuation Method. Because the population has a strong seasonal influence on the wastewater discharge into the estuary, we were able to simulate the feedback loop between the human activities that control water quality and those that benefit from it. We organized a critical evaluation of our efforts with the stakeholders, which allowed us to better understand their perceptions of the strengths, limitations, and opportunities for future SAF applications. Here we describe several aspects of our efforts that demonstrate the potential value of the SAF to environmental managers and stakeholders in clarifying some of the causal mechanisms, management options, and costs for resolution of the conflictual problem between water quality and tourism in the Guadiana estuary.
\end{abstract}

Key Words: blue flag award; cost-benefit analysis; economic base model; Guadiana estuary; systems approach; tourism; water quality

\section{INTRODUCTION}

\section{Guadiana Estuary}

The Guadiana River is situated in the southwestern Iberian Peninsula (Fig. 1) and has a drainage basin area of ca. 66,960 $\mathrm{km}^{2}\left(54,510 \mathrm{~km}^{2}\right.$ in Spain and $12,450 \mathrm{~km}^{2}$ in Portugal; Bettencourt and Ramos 2003). With a total length of $820 \mathrm{~km}$, the last $50 \mathrm{~km}$ of the river forms a natural border between Portugal and Spain. The Guadiana Estuary covers the zone of tidal influence extending $50 \mathrm{~km}$ from the river mouth (Ruiz Muñoz et al. 1996) (Fig. 1). The main estuarine channel depth is generally less than $10 \mathrm{~m}$ with a mean depth of about $5 \mathrm{~m}$ (with respect to mean water level), it experiences a semidiurnal tidal regime with amplitudes ranging from 1.3 to 3.5 $\mathrm{m}$ and, has an average water residence of 58 days during low river flow and 21 days during high river flow (Fortunato et al. 2002, Lobo et al. 2004, Garel et al 2009). The region is characterized by a Mediterranean climate with humid winters and hot dry summers (Bendavid-Val 1991) and freshwater discharge exhibits a pronounced seasonal and annual variability. During winter, when freshwater inflow is greatest, the estuary is vertically stratified with a well-defined salt wedge. During summer, when inflow is at a minimum, it is tidally mixed and has a strong horizontal salinity gradient.

\section{Human settling and activities}

Human impacts on the estuary date back ca. 7000 yrs when there was a sharp decrease in forest cover (based on pollen diagrams; Fletcher et al. 2007). Salt production and gold mining in the Iberian Pyrite Belt have been practiced since Phoenician and Roman times respectively (Delgado et al. 2011). Pyrite mining and transport of processed ore from Pomarão to Vila Real de Santo António became a leading economic activity from the late $19^{\text {th }}$ century until the $1960 \mathrm{~s}$ and at that time large amounts of heavy metals were released into to the estuary and sea. During the first half of the $20^{\text {th }}$ century, the lower estuary hosted one of the largest tuna processing industries in the world, declining thereafter until its closure in the 1970s (Santos 1989). Around the same time, cereals were intensely cultivated as a result of government incentives. Since the 1980s, tourism has become the major economic driver, historically concentrated along the coastal beaches, and following a steady pace of development. Due to its attractive natural environment, the Guadiana Estuary has become a target for a series of new tourism developments (mostly golf courses and luxury resorts) on both the Portuguese and Spanish sides. Several of these investments have failed during the last 2 years due to the combined effects of economic downturn and inappropriate development (Thiel, 2010). 
Fig. 1. Location of the Guadiana river estuary (southwest Iberian Peninsula), including designated bathing areas inside the estuary and in the adjacent coastal zone. Inside the estuary, some undesignated areas are also used for bathing. The beaches with the Blue Flag Award (BFA) are represented by stars and the ones without it by squares. Data on BFA concerns 2011 season. The BFA is an eco-label that guarantees environmental quality of the beaches awarded. The major urban centers are represented by red dots. The blue dot highlights Pulo do Lobo sampling station.

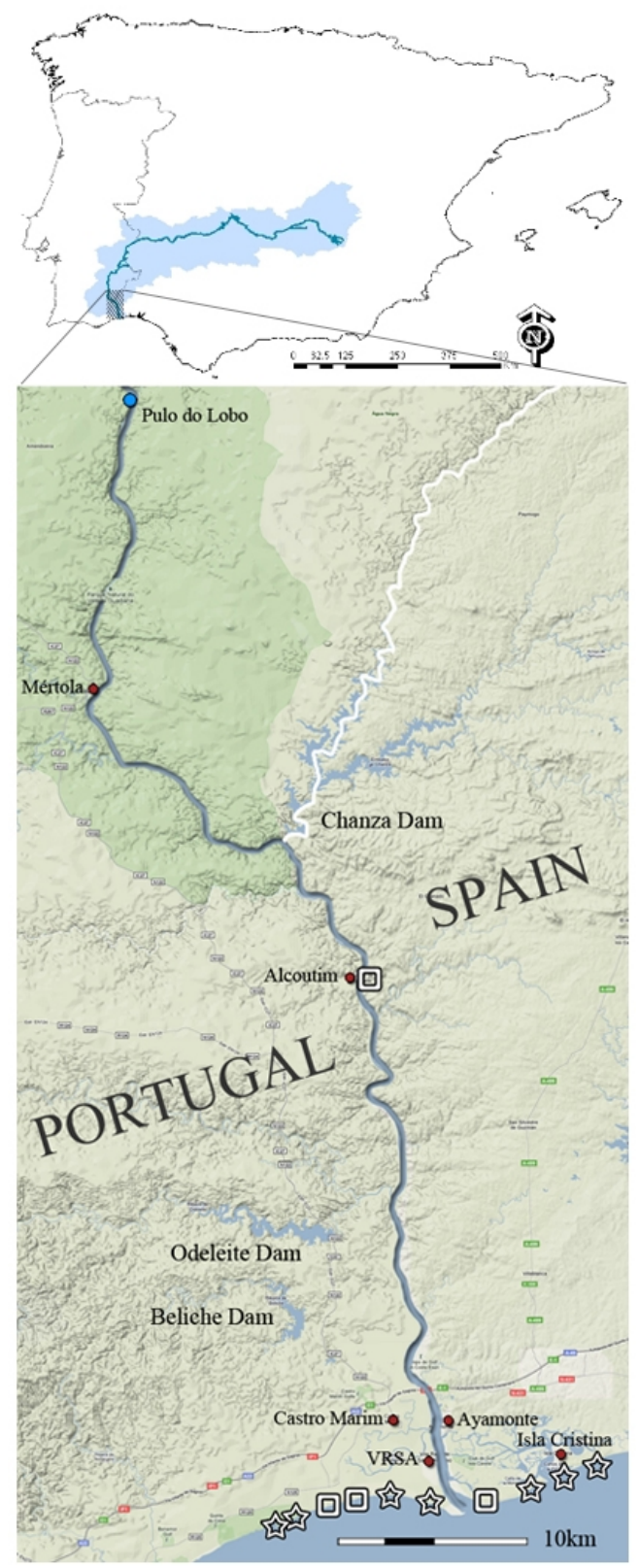

Most of the ca. 50,000 residents of the Guadiana Estuary area (of which $45 \%$ live on the Portuguese side) are employed in the tourism and services sectors. In Spain, tourists increase the population of the coastal municipalities by up to 300,000 in high season, 10 times the resident population (Confederación Hidrográfica del Guadiana 2008). On the Portuguese side, the population increases by up to 212,000 , or 8 times the resident population. Both countries exhibit a similar demographic pattern with a gradual loss in population in the upper estuary's municipalities (circa 4,000 inhabitants) and a gain in the lower estuary (ca. 40,000 habitants). These figures illustrate the local economic importance of recreational activities that bring visitors into contact with the aquatic domain. Since these activities rely on the attractiveness of the environment, it follows that efforts to maintain water quality deserve the attention of local tourism operators and environmental managers.

\section{Blue Flag Program}

In recent years, the certification of environmental quality through eco-labels has become increasingly common (Marin et al. 2009, McKenna et al. 2010). Among these, the Blue Flag Award (BFA) has emerged as one of the most successful ecolabels since its first implementation in 1987. In order to obtain the BFA, several criteria must be met. In 2010, the Blue Flag Program revised its criteria for bathing water quality (following the 2006/7/EC Directive revoking 76/160/EEC Directive). In Portugal, the new Directive was enforced in 2012. Accordingly, in the case of BFA approval, the award is given for the following bathing season with the condition that the site will be monitored for compliance with BFA criteria (FEE 2006). The total number of BFAs varies each year as new sites are awarded, or as old sites are removed. The latter case is often perceived as an indicator of declining water quality that might lead to a reduction in the number of visitors.

On 20 September 2010, 241 Portuguese beaches (http://www. abae.pt), and 600 Spanish beaches (http://www.adeac.es), were granted the BFA. There are seven BFA beaches in the vicinity of the Guadiana Estuary (Fig. 1). However, attempts to win a BFA inside the estuary have failed due to the high variability of water quality, mainly in the summer when the high temperatures and low to negligible river flow favors the proliferation of bacteria. The only official bathing area is located in Alcoutim (Fig. 1) where the first attempts to win BFA failed twice in 2003. This effort was highly publicized in the local media and, subsequently generated a negative perception of the beach and became a concern for local managers.

\section{Water quality status}

Point sources of aquatic pollution are mostly urban sewage discharges and discharges from some industries not connected to the municipal drainage system (Videira et al. 2009). This 
Table 1. BFA fecal coliform thresholds, as defined by EC Bathing Water Directive of 1976 (76/160/EEC).

\begin{tabular}{ccccc}
\hline \hline Parameter & Guide value & $\begin{array}{c}\% \text { of results that can overcome the guide } \\
\text { value }\end{array}$ & $\begin{array}{c}\text { Imperative value } \\
\text { Fe of results that can overcome the mandatory } \\
\text { value }\end{array}$ \\
\hline Fecal Coliforms & $100 / 100 \mathrm{ml}$ & $20 \%$ & $2000 / 100 \mathrm{ml}$ & $5 \%$ \\
\hline
\end{tabular}

problem was acute from 2006 until 2010 due to the release of untreated wastewater, from a $30 \mathrm{~km}$ long collecting pipeline, directly into the estuary. The situation was mitigated in 2010 when the new wastewater treatment plant became operational. There is no data on the change in water quality since routine monitoring is not an obligation in unofficial bathing areas of the estuary.

River flow has been substantially reduced over the past few decades by the construction of over 50 major dams (Brandão and Rodrigues 2000, Trigo et al. 2004). The most recent dam (Alqueva dam, $150 \mathrm{~km}$ from the river mouth) was commissioned in 2002 and increased the retention of freshwater up to $81 \%$ (Morais et al. 2009). Several researchers have linked damming with ecological changes within the estuary, e.g., in planktonic assemblages, ichthyofauna structure, nutrient cycling, and coastal zone productivity (Chícharo et al. 2006a, Chícharo et al. 2006b, Cravo et al. 2006, Sampath et al., 2011).

\section{Objectives}

The transboundary conditions of the estuary add complexity to any governance actions that seeks to improve water quality and, at the same time, highlights the need for a fully integrated approach. Assuring water quality in the Guadiana Estuary is a challenge that requires the collaboration of various public authorities with different responsibilities under the jurisdiction of two countries. We therefore applied the System Approach Framework (SAF) methodology (Hopkins et al. 2011) to the Guadiana Estuary case study (detailed information also available in www.spicosa.eu). Water quality was selected as the primary policy issue. Our simulation scenarios focused on two important management options for improving water quality to a standard that promoted tourism: 1) increasing wastewater treatment and 2) increasing river discharge for greater flushing of the estuary. These scenarios consider three levels of wastewater treatment efficiency for coliform removal $(10 \%, 50 \%$ and $99 \%)$ and four levels of river discharge (observed, half of observed, double observed and drought).

We describe three selected aspects of the SAF: (1) the development of an integrated simulation model for determining estuarine levels of bathing water quality, using fecal coliform as an output variable, (2) the use of the Blue Flag eco-label as a proxy link to simulate the effect of bacterial contamination on the tourist economy, and 3) the participation of stakeholders through discussion and interaction to improve the simulation analysis and to provide a critical evaluation about SAF strengths, limitations, and future opportunities for application.

\section{METHODS}

\section{Simulation set up}

As part of the design step of the SAF, we circulated a questionnaire at the institutional level to help in identifying the Policy Issue. Water quality was the most relevant issue. At that time, there were also frequent discussions of the estuary's water quality in the local media. In addition, answers on the questionnaires pointed to what should be included in the scenarios, since respondents specified regulation of river flow and poor wastewater treatment capacities as important. The scenarios were further detailed in collaboration with stakeholders using face to face and telephone meetings.

The design of the system simulation began with a conceptual model of this Policy Issue (Fig. 2) using CmapTools ${ }^{\circledR}$ software (http://cmap.ihmc.us) and focusing on the causal relationships between changes in water quality and the socioeconomic consequences. Fig. 2 summarizes an iterative process for defining the most relevant variables and processes. The bathing water quality Directive 76/160/EEC of 1976 (Table 1) requires regular monitoring of 19 pollutants therefore the selection of the ecological indicator was a challenge because data on all these parameters were not available. Given that wastewater discharges into the Guadiana Estuary are mainly urban, we decided to assess bathing water quality using the criterion of fecal coliform concentrations and following the thresholds defined in the Directive of 1976 (Table 1). This decision is supported by the new Directive (2006/7/CE) since it solely requires the monitoring of two microbiological indicators of fecal contamination, Escherichia coli and Intestinal Enterococci.

\section{Ecological component}

The simulation model of the Guadiana Estuary used the ExtendSim ${ }^{\circledast}$ software and has been named GUADEX (see http://dataportals.pangaea.de/spicosa/SPICOSA_model_library. $\underline{\mathrm{html}})$. The virtual system of the estuary defined for modeling purposes is depicted in Figure 3. The Guadiana Estuary virtual system was divided into three sectors: upper, middle, and lower, according to distinct ranges of salinity and tidal influence (Wolanski et al. 2006). The ecological component of the model deals with inputs, transport, and decay of fecal coliforms in the estuary (Fig. 4). Transport along the estuary 
Fig. 2. Conceptual model of Guadiana Estuary System used for designing the simulation analysis of the Policy Issue. The box colors represent the modeled components: environmental (light blue), socioeconomic (yellow), ecological-social-economic (ESE) (green) and linking block (blue). Population block is an input to the environmental component and at the same time it's an output of the socioeconomic component, hence it is highlighted. The Blue Flag block makes the simulation model operational by linking the ecological output to the socioeconomic model.

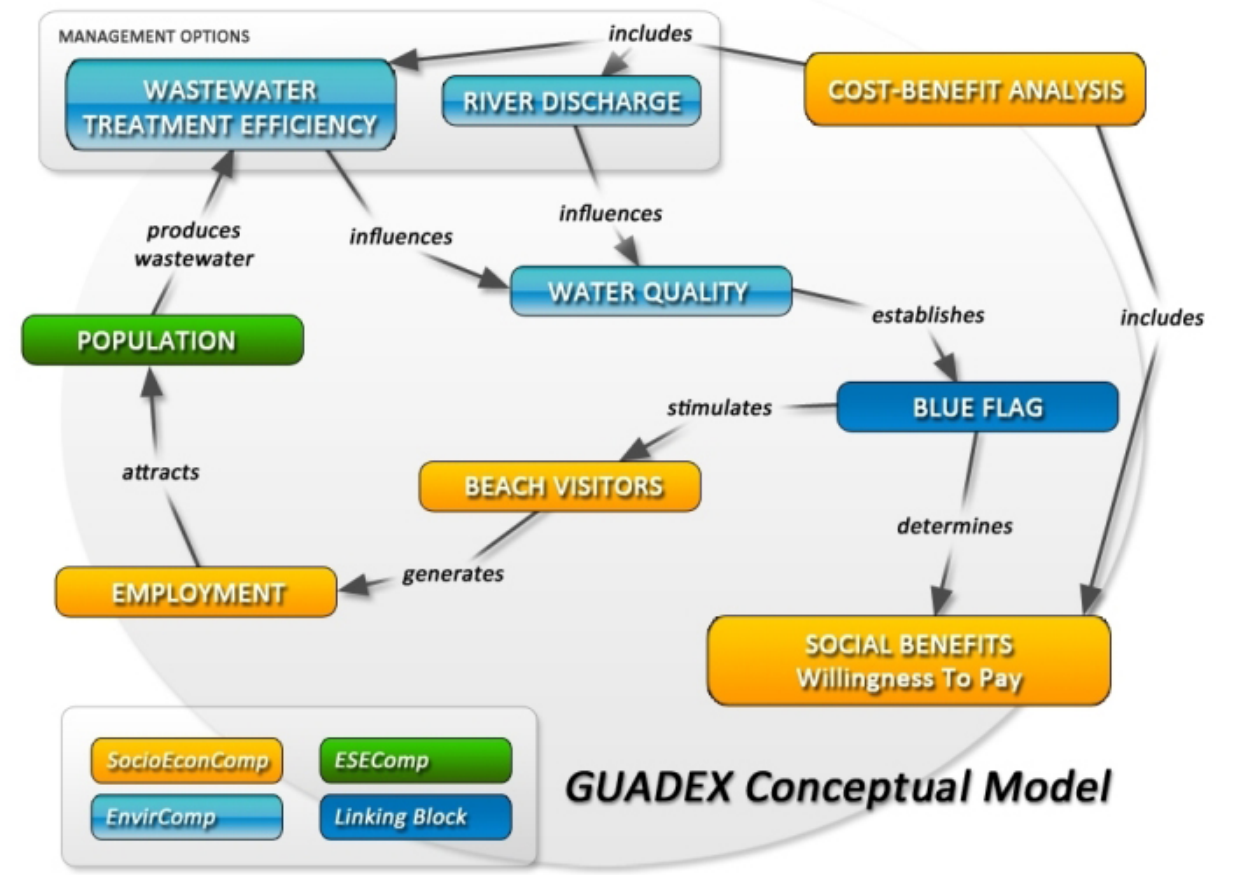

Fig. 3. Guadiana Estuary Virtual System. The bathing areas identified on the map include both the designated and nondesignated areas.

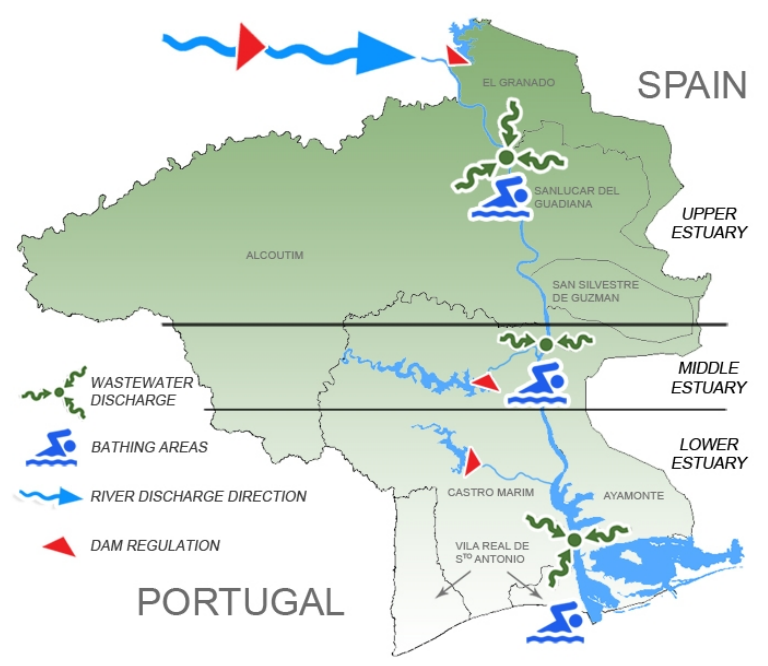

(across sectors) was simulated considering advection and dispersion processes (Equation 3 in Fig. 4, (cf. Abbot and Basco 1989). A salinity transfer model was developed to derive dispersion coefficients along the three sectors. River discharge values ( $Q$ in Fig.4) were extracted from daily records at Pulo do Lobo hydrographic station (ca. $83 \mathrm{~km}$ upstream from the river mouth, Fig. 1) and were included in the transport model (data from the National Water Institute at http://snirh.pt ). These values were augmented by $10 \%$, since, according to Morais et al. (2009), the Guadiana discharge gauged at Pulo do Lobo station equates to $90 \%$ of the total freshwater estuarine flow. River discharge $(Q)$ was also used to build scenarios, as indicated in Fig. 4.

The virtual system includes the several municipal sewage outfalls of the estuary (Fig 3). We estimated these discharge volumes by assuming that the total population $(P)$ of the municipalities for each estuarine sector (upper, middle, and lower) was connected to one wastewater treatment plant and discharged at a single point into each sector (equations 1 and 2 in Fig.4). This means that these discharges are likely overestimated because not all wastewater produced by population is treated by one single plant. The average wastewater production was assumed to be 200 liters/person/ 
Fig. 4. Chain of equations that link environmental component variables in the simulation model. Equation 4 calculates the rate of change of fecal coliforms concentration (FC) in a given estuarine sector. FC depends on: (i) the wastewater coliform load into that sector, dependent on population (P) and the level of fecal coliform removal rate (R), (ii) the transport across the estuarine sector, from upstream to downstream, (iii) bacterial decay.

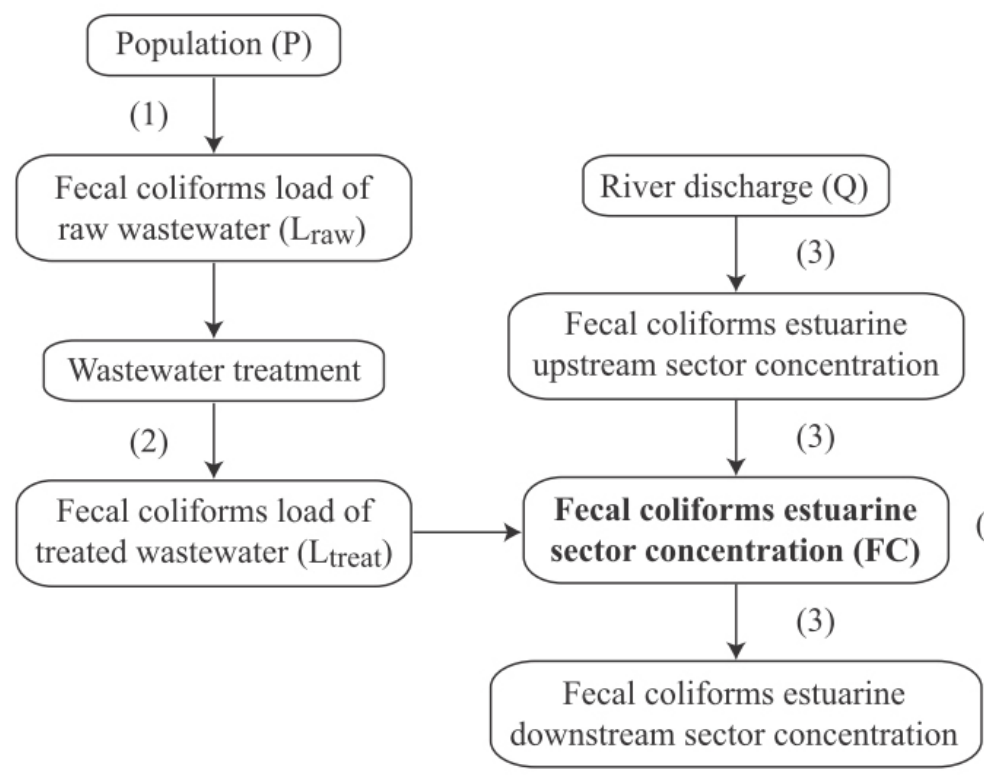

(1) $\mathrm{L}_{\text {raw }}=\mathrm{P} \times 200 \mathrm{~L} /$ day $/$ capita $\times 10^{6} \mathrm{MPN} / \mathrm{L}$

(2) $\mathrm{L}_{\text {raw }}=\mathrm{L}_{\text {treat }}-\left(\mathrm{L}_{\text {raw }} \times \mathrm{R}\right)$

$R$ is removal rate according to scenarios of wastewater treatment efficiency $(10 \%, 50 \%, 99 \%)$

(3) $\frac{\partial C}{\partial t}=-\frac{\partial}{\partial x}(u C)+\frac{\partial}{\partial x}\left(D \frac{\partial C}{\partial x}\right)-$ Decay $u=\frac{Q}{V}$

$Q$ is river discharge: 3 scenarios built on observed data (observed, half of observed, double of observed) and 1 scenario of drought $\left(2 \mathrm{~m}^{3} / \mathrm{s}\right)$

$V$ is the volume of a given estuarine sector

$D$ is the diffusion coefficient

Decay $=$ decay rate of a given estuarine sector $\mathrm{x}$ fecal coliforms mass at $\mathrm{t}-1$

(4) $\mathrm{FC}=\left(\frac{\partial C}{\partial t}\right) / V$

day and the average fecal coliform concentrations in raw wastewater were $10^{7}$ MPN/100 ml (Metcalf and Eddy 1995, equation 1 in Fig. 4 and Fig. 6). Equation 2 represents the wastewater treatment that will ultimately determine the fecal coliform loading into each estuarine sector from wastewater treatment plants. It is used to evaluate the scenarios based on wastewater treatment efficiencies by changing the removal rate $(R)$. The bacterial decay of Equation 3 of Fig. 4 was estimated by optimizing the decay rates that best fit the historical data on fecal coliform concentrations (Fig. 5), which is in line with the findings of Sousa (2008). Data collected for the simulation model and its calibration covered the period from February 2002 (after commissioning of the Alqueva dam) to December 2007. The output of the ecological component is the concentration of fecal coliforms in estuarine waters.

This output was used to link the ecological component with the socioeconomic component through the Blue Flag model block. This block accumulates the number of days with good, acceptable, or bad conditions, according to Council Directive 76/160/EEC (Table 1). The sampling occurred during the bathing season for 139 days from 15 May to 30 September. Considering this annual sampling period, and a daily sampling regime, the guideline threshold (Table 1) should not be
Fig. 5. Example of a calibration plot for the ecological component of GUADEX (daily time step). The solid blue line represents modeled fecal coliform concentrations and individual points represent historical (measured) concentrations in the upper estuary. The solid pink line represents the fecal concentration threshold.

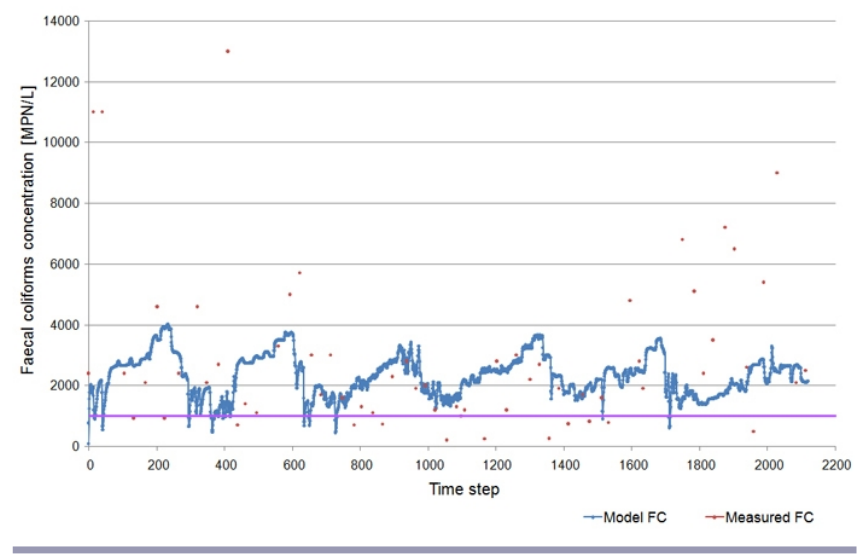


Fig. 6. Chain of equations that link variables in the simulation model. V- beach visitors, TI- urban beach with intensive use. YBF- accumulated years for which the beach is awarded the Blue Flag (BFA), SA- area available to bathers, Eb- number of employed people in the HoReCa (hospitality) sector, EB - total basic employment in the area, P-population.

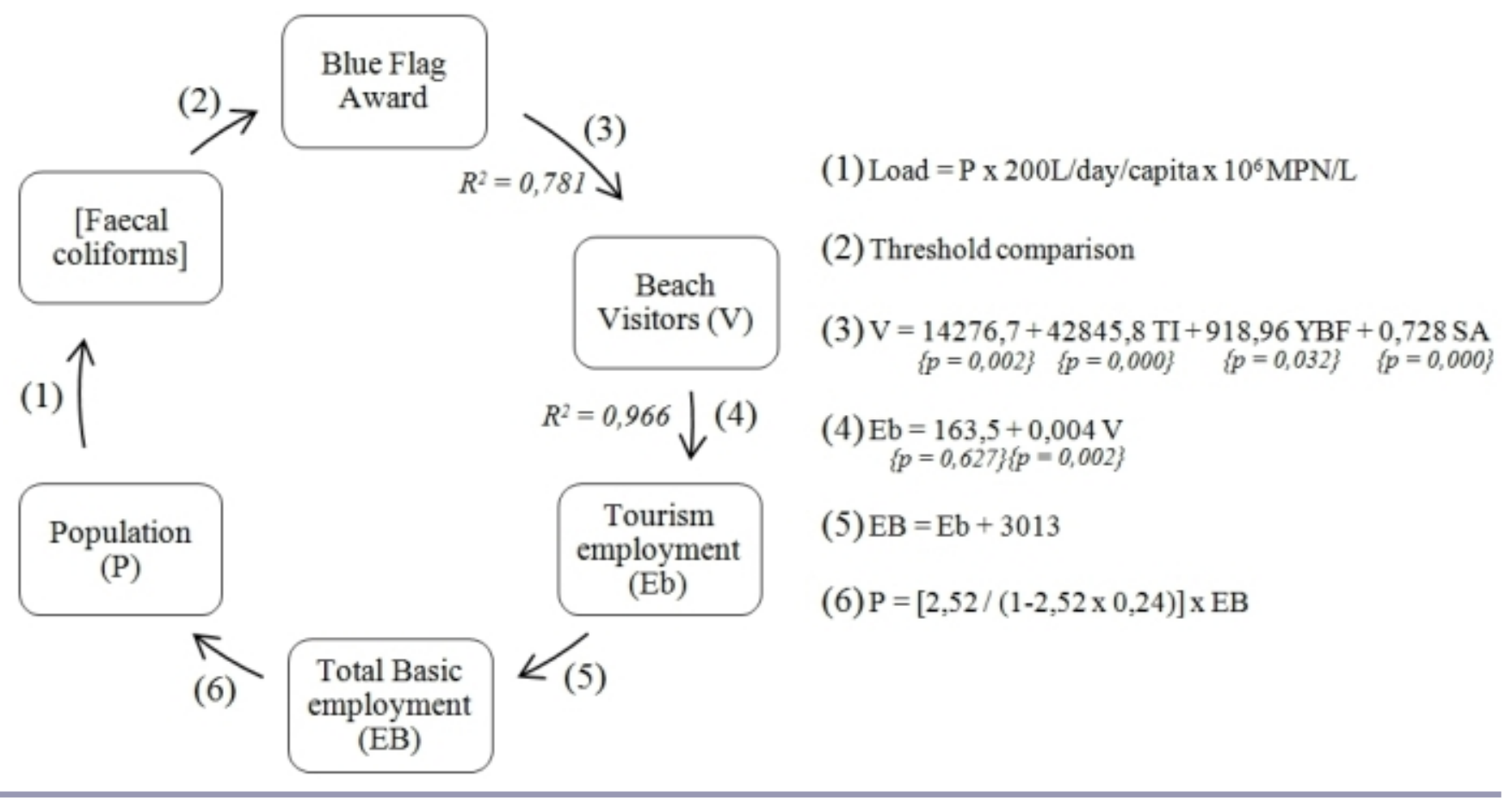

exceeded during 28 or more days and the mandatory value on seven or more consecutive days. The output of this rationale is the linking block that defines whether there will be conditions for attributing the BFA in each estuarine sector.

\section{Blue Flag Link}

Linking the environmental parameters to economic activity represents a methodological problem, since the latter is indirectly related to physical-chemical water parameters. This was overcome by coupling the environmental-socialeconomic components of the system, using BFA as a proxy for water quality. For each level of treatment, the number of days exceeding BFA conditions were calculated in order to verify whether a BFA could be awarded or not for each year of the simulation. This binary decision is then used as an input variable for calculating socioeconomic impacts, as explained in the next section (process 2 in Fig. 6).

\section{Socioeconomic component}

The socioeconomic component of the simulation model was developed using two complementary approaches: an extended Economic Base Model (EBM) and a Cost Benefit Analysis (CBA). The EBM model is used to represent the cascading effects of water quality on the tourism frequentation, number of tourists on the employment, level of this employment on resident population, and ultimately on the need for investments and the benefits for obtaining different levels of water quality. Thus, the EBM by analyzing the causal relationship between changes in water quality and, ultimately, the number of inhabitants, creates a feedback loop between the environmental and the socioeconomic components of the system (Fig. 2).

EBM defines export activities as the basic propulsive factors in the economy (Hoyt 1939, North 1955, Tiebout 1956, Costa et al. 2005). All the other economic activities are designated as non-basic. In the case of tourism, the local economy attracts external revenues by "selling" to the tourists its "sun and beach" resources. In other words, the revenues by hotels, restaurants, cafés and souvenir shops are considered as exports in an economic sense. If there is an increase in the demand for these exports from a given region, then conditions are set for the expansion of the basic sector in that region. This, in turn, generates an expansion in the supporting activities in the nonbasic sector (Bendavid-Val 1991). In the case of Guadiana, tourism is the core, or base, of the Economic Base Model (EBM) since this is one of the main economic drivers in that region (Guimarães et al. in press). Thus the financial inflow into the region's economy from tourism is the "economic base" of the region's economy. In the same way, export demand generates increased employment and more demand for regional production and services (Berck and Hoffman 2002).

For the first step in the development of EBM, we determined how beach visitors respond to a water-quality change, 
Fig. 7. CBA outputs in GUADEX environment according to the three wastewater treatment efficiency scenarios for coliform removal: A - 99\%; B - 50\%; C - 10\%. The final output represents the cost/benefit ratio taking into account a 20-year lifespan.

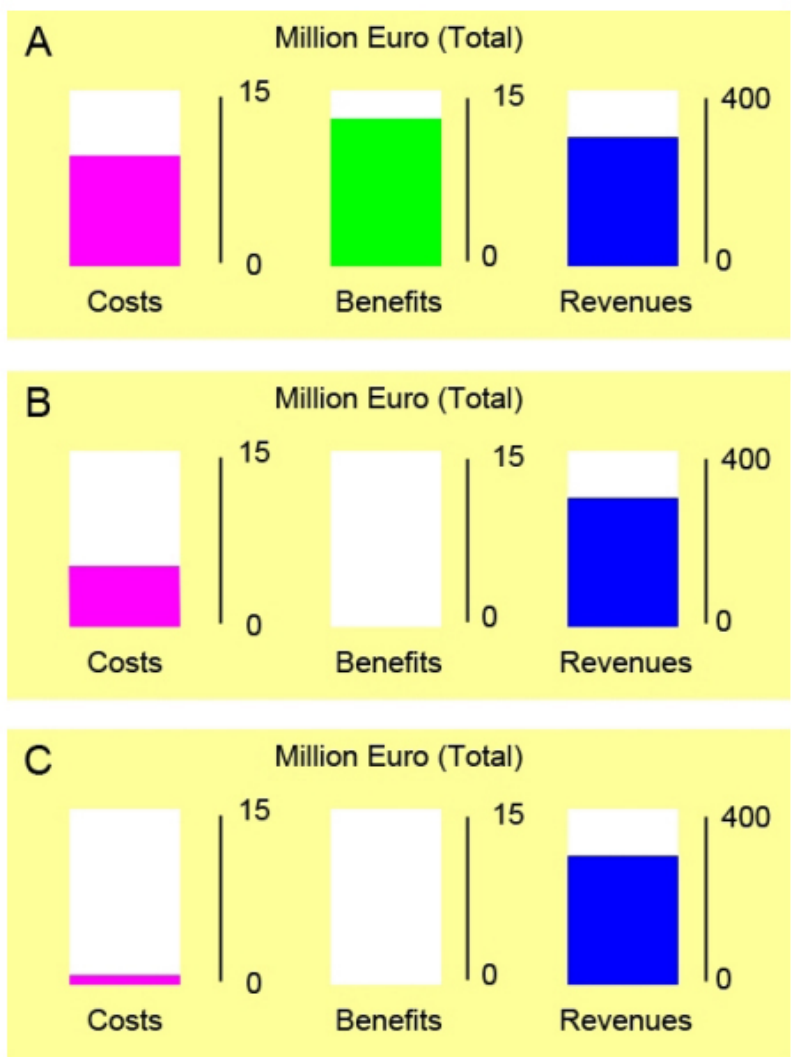

\section{Costs}

Costs are the highest in option A since the investment represents the required for tertiary treatment. The costs error margin was not quantified. Used values represent estimations taking into account data provided by the responsible institution.

\section{Benefits}

Represent willingness to pay (wtp) obtained by Contingent Valuation (CV). Residents wtp was $47,17 €$ with a standard deviation of 52,75€. Benefits do not exist in option $\mathrm{B}$ and $\mathrm{C}$ due to lack of compliance with the scenario presented in $\mathrm{CV}$ application.

\section{Revenues}

It represents the sanitation tax that residents pay to the responsible institution. Since this institution manages the sewage of the region the rate is the same to all Algarve residents, regardless of the service provided to a certain locality.

Cost-Benefit Analysis for 20 years ( the average time span of the facilities). represented by the presence or absence of the BFA. Data from the Regional Development and Coordination Commission (CCDR Algarve), obtained during surveys of the number of beach visitors and beach facilities (e.g. access, parking, lifeguards) in 2002 were compared to data from the National Blue Flag Association, i.e., historical BFA status since 1987. From this combined data set $(n=69)$, the following variables were chosen for subsequent multiple regression analysis: quantity of visitors (dependent variable), available beach surface, total years with BFA, and type of beach (urban with and without intensive use, semi-natural or natural). Next, we quantitatively defined how the number of beach visitors was affecting employment in the tourism sector. For that purpose, the average number of visitors to 60 beaches was confronted with employment figures in the Hotel, Restaurant and Café (HoReCa) sector. Thus, regression analysis was performed on number of visitors and the number of workplaces created in the HoReCa sector, showing a strong positive correlation $\left(\mathrm{R}^{2}=0.966\right.$; Equation 4 in Fig. 6).

Lastly, we used the EBM to portray how an increase in employment affected the resident population by using Czamansky's (1964) formula. This formula is based on the assumption that an increase in economic activity causes population growth (equation 5 and 6 in Fig. 6). This last step allowed completion of the feedback loop described in Fig. 2. In the first year of simulation, we used population figures provided by the Portuguese and Spanish national statistical bureaus on: 1) resident population, and 2) tourist population. We obtained the tourist population from the ratio of tourist per residents and used it at every time-step of simulation (e.g., through a ratio per month that is multiplied by the resident population). In equation 5 (Fig. 6), the value 3013 stays for the amount of people employed in the HoReCa sector at time step 0 (official statistical data). After the first year's simulation, the resident population is an output of the model itself (Equation 6 in Fig. 6). The resident population equation is based on the extension of EBM proposed by Czamansky (1964) and relies on the calculation of population $(0,24)$ and employment $(2,52)$ multipliers from the 2001 national census data (Guimarães et al. in press) (cf. Curtis and Kuehn 1967; Schaffer 1999; Quintero 2007).

The CBA is used to provide a synthetic evaluation of cost and benefits of different scenarios. The CBA is divided into two components: financial and economic (Fig. 7). For each 
Table 2. List of stakeholders in the participant group.

\begin{tabular}{|c|c|c|c|}
\hline $\begin{array}{l}\text { Stakeholder } \\
\text { category }\end{array}$ & $\begin{array}{l}\text { Number of } \\
\text { participants in } \\
\text { each meeting }\end{array}$ & Institution & Stake related to policy issue \\
\hline \multicolumn{4}{|l|}{ Public } \\
\hline \multicolumn{4}{|c|}{ Governmental } \\
\hline & 3 & Management of the water basin of Alentejo region & $\begin{array}{l}\text { Regional water resources authority; implementation of Water } \\
\text { Framework Directive }\end{array}$ \\
\hline & 4 & Algarve water basin management & \\
\hline & 3 & $\begin{array}{l}\text { Castro Marim and Vila Real de S. António } \\
\text { saltmarshes Natural Reserve }\end{array}$ & Conservation of the salt marsh and biological communities \\
\hline & 1 & Câmara Municipal de Vila Real de Santo António & $\begin{array}{l}\text { Local municipality; definition of socioeconomic development } \\
\text { strategies }\end{array}$ \\
\hline \multicolumn{4}{|c|}{ Non-Governmental } \\
\hline & 5 & Ecologists in Action & $\begin{array}{l}\text { Active participation in the defence of environmental quality } \\
\text { (e.g., monitoring waste discharges, environmental education, } \\
\text { complaints to municipalities) }\end{array}$ \\
\hline & 2 & Almargem - natural heritage defence & \\
\hline & 2 & Woods and environment Friends & \\
\hline \multicolumn{4}{|l|}{ Semi-Private } \\
\hline & 1 & Alqueva dam management & Management of river discharge controlled by Alqueva dam \\
\hline & 5 & Wastewater management company & $\begin{array}{l}\text { Implementation and maintenance of urban wastewater } \\
\text { treatment facilities }\end{array}$ \\
\hline \multicolumn{4}{|r|}{ ( } \\
\hline & 2 & $\begin{array}{l}\text { NEMUS - environmental requalification } \\
\text { management company }\end{array}$ & $\begin{array}{l}\text { Environmental assessment of large projects (e.g., navigation } \\
\text { channel dredging); elaboration of river basin management } \\
\text { plans }\end{array}$ \\
\hline & 1 & Salt farming company & $\begin{array}{l}\text { Traditional economic activity dependent on both water } \\
\text { quality and consumers' perception of ecosystem health }\end{array}$ \\
\hline
\end{tabular}

simulation scenario, the financial component was estimated from data on investment, operation costs, and revenues (local sanitation tax) obtained by the company managing wastewater treatment plants. The economic component of CBA was estimated from the relationship between human welfare and changes in water quality. We established this relationship empirically by the Contingent Valuation (CV) using the Willingness to Pay (WTP) technique (see Guimarães et al. 2011). The WTP survey targeted the resident population of the virtual system (Fig. 3) and intended to measure in monetary terms the non-monetary benefits that water quality improvement would generate among residents. The CV application included a pilot survey and a final questionnaire distributed to 300 residents of both margins of the estuary taking into consideration population density (Guimarães et al. 2011). All values were discounted by $5.5 \%$, as recommended for Portugal by the European Union. The average WTP per adult (onetime payment) estimated was 47.14 Euros for a water quality improvement that would guaranty the existence and maintenance of a BFA for all beaches within the estuary. CBA results are presented in the simulation model by a column chart (e.g., Fig. 7) that includes 3 columns: cost and revenues columns include data on the financial component while the benefit column represents the population aggregated WTP value.

\section{Stakeholders' interaction}

Towards the end of the system appraisal step, and at the beginning of the system output step, a series of more intensive meetings with participant groups were organized (Table 2). Their main goal was to discuss the outputs and utility of SAF/ GUADEX with managers of the estuary. Subsequent to these meetings, we organized a public forum in July 2010. Each meeting had a planned duration of two hours and a four-fold goal: 1) discussion of ICZM; 2) SAF implementation in the Guadiana Estuary; 3) GUADEX model results and discussion; and 4) an evaluation questionnaire. The research team members acted as communicator, moderator, and facilitator during these meetings, while also recording information for analysis. GUADEX outputs were presented in an edited form due to time limitations. Ten meetings were organized and involved 30 participants ( 1 to 6 participants per meeting).

\section{RESULTS}

\section{Ecological model}

The GUADEX model can be directly displayed in the ExtendSim ${ }^{\circledR}$ environment, making use of its interactive design capabilities (http://dataportals.pangaea.de/spicosa/SPICOSA model_library.html; http://www.cima.ualg.pt/cimaualg/cimau alg old/SPICOSA/local/). The possible scenarios in GUADEX consider three levels of wastewater treatment 
efficiency for coliform removal (10\%, 50\% and 99\%) and four levels of river discharge (observed, half of observed, double observed and drought). The model outputs results included: river discharge and fecal coliform concentration charts; cumulative number of days with good, acceptable, or bad water quality; beach visitors; number of individuals employed in tourism; resident population charts; and CBA values.

River discharge did not appear to be a critical factor affecting fecal coliform concentration in the estuarine waters despite its paramount importance in transferring nutrients from the drainage basin to the estuary. Although different river discharge scenarios give different coliform concentrations for the same removal efficiency, they do not dominate over the influence of coliform removal efficiency. GUADEX results show that the estuary could achieve the water quality required for BFA with $99 \%$ efficiency of coliform removal possible by a third-level wastewater treatment.

\section{Socioeconomic model}

Although the 99\% scenario represents the highest cost (ca. 9.4 $\mathrm{M} €$ ), the CBA indicates that the economic benefits surpass the costs by ca. 3.1 M€ (Fig. 7) over a 20-yr period. The EBM results show that the number of beach visitors was strongly correlated $\left(R^{2}=0.781\right)$ with the cumulative effect of the BFA (i.e., the total number of years that a beach had BFA) and with the available surface area and beach type (Equation 3 in Fig. 6). Hence, the $99 \%$ wastewater treatment efficiency is also the only scenario for which visitors, employment, and population figures are expected to increase significantly, i.e. by 4600,18 , and 344 respectively, after 5 yrs.

\section{Stakeholder feedback}

From the meetings' reports and questionnaire analysis, we obtained information on: stakeholders' understanding of the ICZM concept at European, national, and regional scales; the adequacy of the SAF as a supporting tool for ICZM; the robustness and attractiveness of the GUADEX simulation model; the effectiveness of our communication strategy; and the stakeholders' motivation to participate in similar initiatives. We believe that the most important aspect of these meetings was the critical evaluation by external and involved parties of the whole process of SAF implementation and development in the Guadiana Estuary. The discussions of the SAF protocol and its outcomes allowed us to better understand stakeholders' perceptions of its strengths, limitations and future opportunities for application (Fig. 8). The use of BFA as a proxy link was the most reported issue across the meetings, and is thus worth examining in detail.

A categorized rating of both SAF and GUADEX by stakeholders' while replying to the questionnaires (Fig. 9) demonstrates how the stakeholders truly appreciate the integrated character of our experiment, which greatly supplements the descriptive character of ICZM activities. The innovation of SAF scored between high and fair and respondents (74\%) demonstrate a high level of interest in the SAF approach. Most of them understood the rationale and functioning of the model and its usefulness for expanding the methodology to other sectors of the estuary.

\section{DISCUSSION}

\section{BFA as a management tool}

Results from interaction with the participant groups showed that, although the BFA provided a link between ecological and socioeconomic components, stakeholders held some reservations about the trustworthiness and applicability of this eco-label (Fig. 8). We received several remarks about BFA voluntary application, related to candidature costs, dependency on criteria other than bathing water quality, and to monitoring procedures. Also, it was noted that public awareness of the value of the award was low. These reservations are similar to those reported by other authors (see Buckley 2002, Boevers 2008). Water quality is a relevant parameter for eco-labels, although these instruments do not imply improvement, only recognition (McKenna et al. 2010). According to McKenna et al. (2010), management authorities generally regard public perception of water quality as the only significant driver for seeking eco-labels such as the Blue Flag. Therefore, local authorities will be strongly discouraged from applying for a BFA if they know that a certain bathing area does not meet the approved quality standards. Indeed, they are frequently powerless to improve water quality, being, in many cases, not directly responsible for wastewater treatment. This is the case for the Portuguese side of the Guadiana Estuary, where wastewater treatment responsibilities have been transferred from municipalities to a public company.

Another reservation held by some of the consulted stakeholders was connected to the legal thresholds used for determining the attribution of the Blue Flag. The new Directive 2006/7/EC provides that assessment of the status of bathing water is based on the concentration of Intestinal Enterococci and Escherichia coli in the last four years (which is used to build a "beach profile"), instead of a single year's result as per the former Directive 76/160/EEC. According to 2006/7/EC the frequency of reviews is to be determined on the basis of the nature and severity of pollution. Therefore where water quality is consistently good over a three-year period, sampling frequency may be reduced. At the time of GUADEX's development, the government authority responsible for monitoring bathing waters had not yet implemented the technical procedures for this new method of evaluation. Some stakeholders therefore stressed the need to update the simulation model in order to reflect the new legal framework (Fig. 8). In terms of modeling, this new legal framework requires, that the awarding of the BFA in a given year depends on water-quality monitoring results from previous years. Stakeholders suggested that the flexibility of GUADEX allows it to be easily adapted to the new legal framework of 
Fig. 8. Qualitative information obtained during bilateral meetings where SAF implementation was summarized and GUADEX was presented to stakeholders.

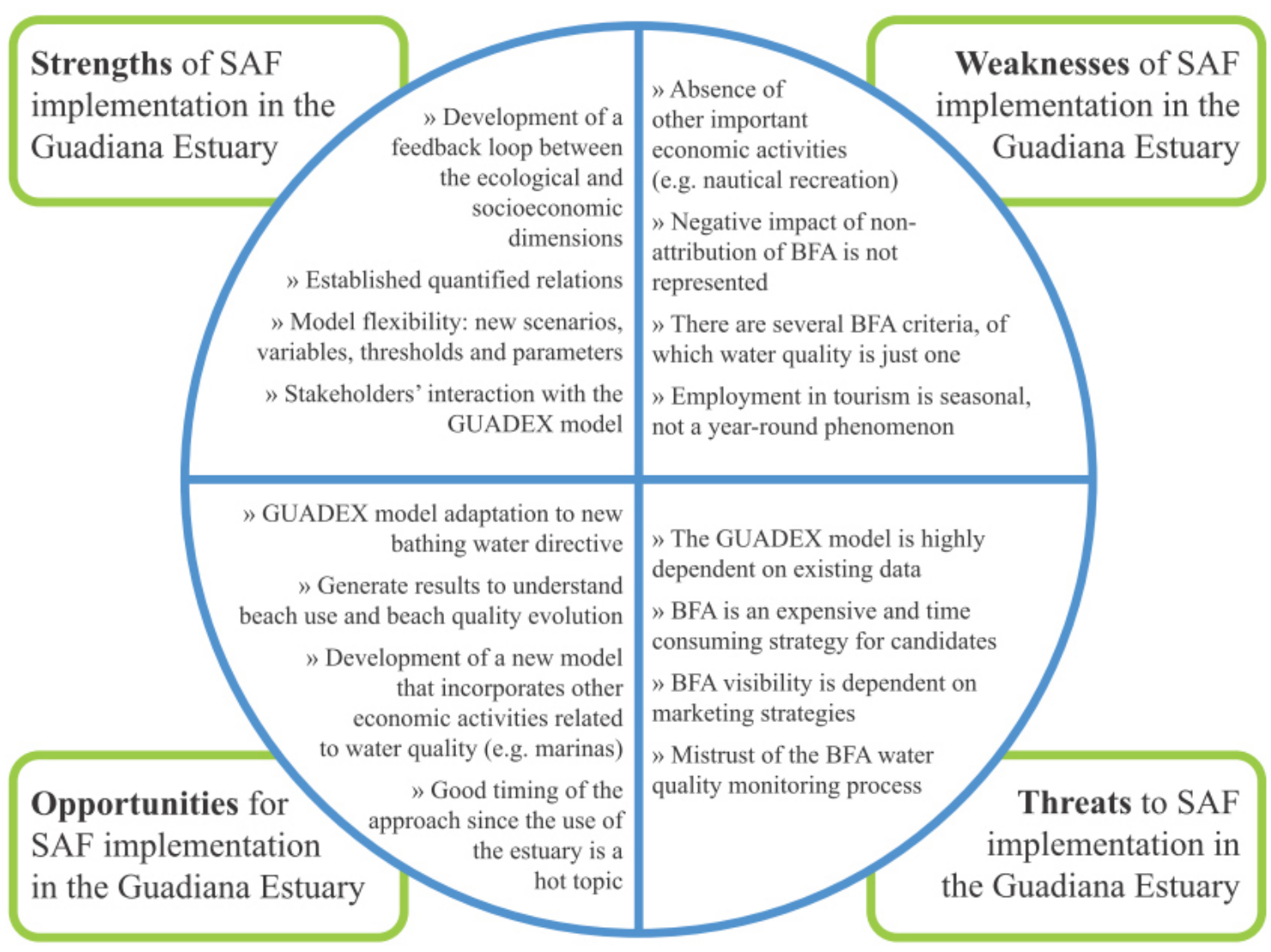

bathing water quality and also suggested the development of scenarios in terms of variability in tourist flux (Fig. 8 and 9). Despite these reservations and in agreement with stakeholders GUADEX is considered of great assistance to beach management if upgraded to the new monitoring program.

\section{Contribution of EBM and CBA}

Although EBM established a clear relation between the beach visitors, employment, and number of inhabitants, stakeholders raised concerns about the seasonal character of employment. Seasonality of employment, which is intrinsic to the tourism sector, is an important issue when dealing with economic development and sustainability, and is a recurrent topic in the literature (Ashworth and Thomas 1999, Krakover 2000, Parrilla et al. 2007). However, the available data on the number of employees in this sector does not yet allow us to discern clearly between permanent and seasonal workers (Fig. 2 and $6)$. EBM results per se could imply an extra impact in the ecological system; however results show that this increase is small and the demonstration of an existing feedback loop implies that, in order to maintain this growth, good water quality would be essential.
Fig. 9. Stakeholders' evaluation of SAF and GUADEX after bilateral discussions with researchers.

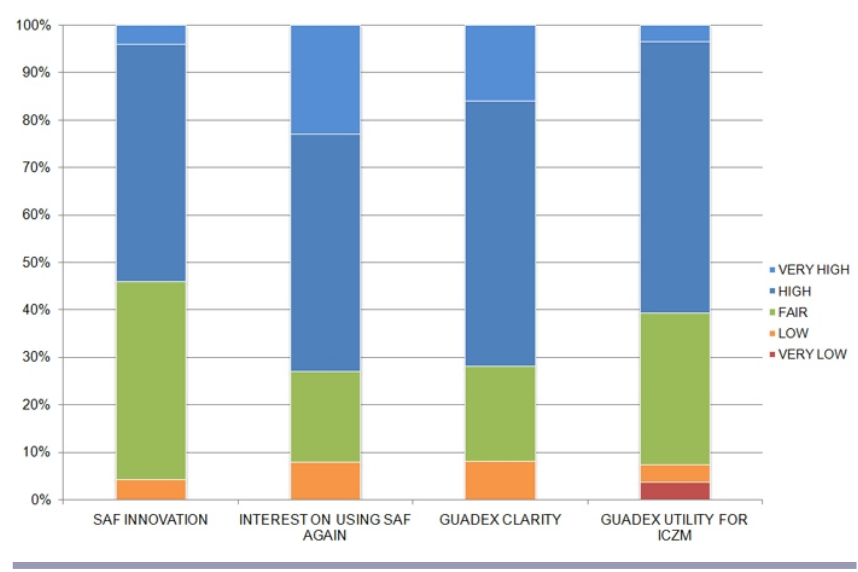

Results (Fig. 8) show that CBA did not promote discussion among stakeholders because of the lack of familiarity with 
principles of environmental economics. This might be explained by the fact that performing CBA including externalities is not an obligation under national law and not a common practice among managers (Madureira et al., 2007). The main achievements of CBA exercise were the inclusion of non-market values obtained by CV exercise (Guimarães et al., 2011) and showing that human welfare benefits are only achieved when the wastewater treatment attains $99 \%$ of efficiency. We were expecting some discussion concerning possible inclusion of other less costly management alternatives (i.e., less efficiency of waste treatment and redirection of the wastewater discharge). However the lack of stakeholder's interest in that issue may be explained by the fact that budget has already been allocated to increase the level of treatment until 99\% efficiency. The CBA also shows that residents are paying the same sanitation tax despite the level of water treatment efficiency. Questions remain concerning the awareness of the general public about this fact as well as the level of agreement with this policy.

\section{Future opportunities and limitations}

Despite the limitations recognized by stakeholders, the general opinion of the SAF/GUADEX integrated approach and its usefulness was positive. In particular, the model's capacity to clearly show results linked across ESE components was highly appreciated. Several suggestions were put forward in terms of improvement in the model output within the same policy issue (Fig. 6), being the most relevant: changes of nutrients concentration in estuarine waters and impacts on fisheries and, the impact of high number of tourist and of recreational navigation on the estuarine water quality.

The stakeholders involved in this stage were mainly from the Portuguese side of the border (Table 2), despite our efforts to maintain contact with Spanish stakeholders. Our inability to ensure engagement of more stakeholders in the consultation process was certainly a shortcoming of the exercise. We believe that, with time, interest will increase and partnerships will consolidate, since this type of synergy is neither static, nor limited to the time frame of the project.

As Pennington (2008) states, a set of individuals representing diverse perspectives and interests must learn how to use a collective conceptual framework as a springboard for creative problem solving. The SAF can facilitate such a process, and its application to the Guadiana Estuary proved to be useful by clearly demonstrating the multiple institutional relationships that must exist for ICZM. For example, the Guadiana area's municipalities, which are interested in having the BFA in their bathing areas, are dependent on water quality. The latter, however, is under the control of a wastewater management company. SAF application in the Guadiana study site received positive feedback from stakeholders and proved to be an effective communication tool (Fig. 9). Its implementation brought clear benefits, such as increasing multidisciplinary work among the scientific community, creating a common ground between science and policy, and promoting discussion about the estuarine system. This has sparked interest in applying the same approach to address other policy issues and in expanding the outputs of the current model.

\section{CONCLUSION}

The simulation model for the Guadiana Estuary was implemented as part of the SAF experiment to test the use of a system approach for simulating responses in complex coastal systems, the effectiveness of providing useful information on policy options, and the value of incorporating stakeholder participation in the process. Its development required the acquisition of data from highly diverse sources, revealing significant data gaps in the process. This had both negative and positive aspects. On one hand, it required adjustments to the objectives and modeling strategy, since only available data could be used. On the other hand, it helped develop simulation skills and to establish working relationships with several stakeholders and other research groups in possession of the required data.

A major benefit brought about by this SAF exercise in the Guadiana Estuary was the establishment of research relationships between several institutions. This could open avenues for a second iteration of SAF, since future data gathering will be less time-consuming and the time-gap between model development and the need for decision-making will be reduced. As intended, SAF is an iterative and on-going process.

Work is underway to establish a link between estuarine nutrient fluxes and a socioeconomic component in fisheries. The integration of this new simulation loop in GUADEX should lead to a better understanding of combined impacts of efficiency in wastewater treatment and river discharge. Consequently the model output will provide technical options for management of dams and urban sanitation. In addition, the socioeconomic impact of the beach sediment budget in the transboundary area of the river mouth is currently being tested and will be the next SAF application in our case-study site. SAF application is therefore a self-evolving, iterative process in which the end product of one application may lead to the beginning of another, thus fulfilling the basic ICZM requirement.

Responses to this article can be read online at: http://www.ecologyandsociety.org/voll7/iss3/art38/ responses/

\section{Acknowledgments:}

The authors would like to thank the European Commission for financial support of this work as part SPICOSA Project - 
Science and Policy Integration for Coastal Systems Assessment, Contract no. 036992 in the 6th framework program, priority 1.1.6.3: Global Change and Ecosystems, which the Center of Marine and Environmental Research (CIMA) is a participant. Thanks are due to the people that work and live along Guadiana Estuary who participated in this project. The authors would also like to thank Simon Connor for helpful comments on an earlier draft.

\section{LITERATURE CITED}

Ashworth, J., and B. Thomas. 1999. Patterns of seasonality in employment in tourism in the UK. Applied Economics Letters 6:735-739.

Barbosa, A. B., R. B. Domingues, and H. M. Galvão. 2010. Environmental forcing of phytoplankton in a Mediterranean estuary (Guadiana Estuary, South-western Iberia): a decadal study of anthropogenic and climatic influences. Estuaries and Coasts 33:324-341. http://dx.doi.org/10.1007/s12237-009-9200$\underline{\mathrm{x}}$

Bendavid-Val, A. 1991. Regional and local economic analysis for practitioners (4th edition). Praeger, New York, pp. 238.

Bettencourt, A. and L. Ramos. Editors. 2003. Estuários Portugueses. Plano Nacional da Água, Direcção dos Serviços de Planeamento, Instituto da Água, Ministério das Cidades, Ordenamento do Território e Ambiente, Lisboa, pp. 326.

Berck, P. and S. Hoffmann. 2002. Assessing the employment impacts of environmental and natural resource policy. Environmental \& Resource Economics 22: 133-156. http://dx. doi.org/10.1023/A:1015531702905

Boevers, J. 2008. Assessing the utility of beach ecolabels for use by local management. Coastal Management 36:524-531. http://dx.doi.org/10.1080/08920750802398776

Brandão, C., and R. Rodrigues. 2000. Hydrological simulation of the international catchment of Guadiana River. Physics and Chemistry of the Earth Part B-Hydrology Oceans and Atmosphere 25:329-339. http://dx.doi.org/10.1016/S1464-1909 (00)00023-X

Buckley, R. 2002. Tourism ecolabels. Annals of Tourism Research 29:183-208. http://dx.doi.org/10.1016/S0160-7383(01) $\underline{00035-4}$

Chícharo, L., M. A. Chícharo, and R. Ben-Hamadou. $2006 a$. Use of a hydrotechnical infrastructure (Alqueva Dam) to regulate planktonic assemblages in the Guadiana Estuary: basis for sustainable water and ecosystem services management. Estuarine Coastal and Shelf Science 70:3-18. http://dx.doi.org/10.1016/j.ecss.2006.05.039

Chícharo, M. A., L. Chícharo, and P. Morais 2006b. Interannual differences of ichthyofauna structure of the Guadiana
Estuary and adjacent coastal area (SE Portugal/SW Spain): before and after Alqueva dam construction. Estuarine Coastal and Shelf Science 70:39-51. URL: http://dx.doi.org/10.1016/j. ecss.2006.05.036

Confederación Hidrográfica del Guadiana. 2008. Esquema provisional de temas importantes - Parte Española de la demarcación hidrográfica del Guadiana. Ministerio de Medio Ambiente y Medio Rural y Marino, pp. 39.

Council Directive 76/160/EEC of 8 December 2012 concerning the quality of bathing water.

Council Directive 2006/7/EC of 15 of February 2006 concerning the quality of bathing water and repealing Directive 76/160/EEC.

Costa, S. J., P. A. Delgado, and M. I. Godinho. 2005. A teoria da base económica. in Regional, A.-A.P.P.0.D. (Editor) Compêndio de Economia Regional $2^{a}$ Edição. APDR Associação Portuguesa para o Desenvolvimento Regional, Coimbra pp. 787-295.

Cravo, A., M. Madureira, H. Felícia, F. Rita, and M. J. Bebianno. 2006. Impact of outflow from the Guadiana River on the distribution of suspended particulate matter and nutrients in the adjacent coastal zone. Estuarine, Coastal and Shelf Science 70:63-75. http://dx.doi.org/10.1016/j.ecss.2006 .05 .034

Czamanski, S. 1964. A model of Urban Growth. Papers in Regional Science 13:1177-1200. http://dx.doi.org/10.1007/BF $\underline{01942568}$

Decree-Law no. 135/2009 of 3 of June 2009 transfers the directive 2006/1/CE to the national law concerning quality of bathing water.

Delgado, J., C. Barba-Brioso, J. Nieto, T. Boski. 2011. Speciation and ecological risk of toxic elements in estuarine sediments affected by multiple anthropogenic contributions (Guadiana saltmarshes, SW Iberian Peninsula): I. surficial sediments. Science of the Total Environment 409, 3666-3679. http://dx.doi.org/10.1016/j.scitotenv.2011.06.013

Fletcher, W. J., T. Boski, and D. Moura. 2007. Palynological evidence for environmental and climatic changes in the lower Guadiana valley (Portugal) during the last 13,000 years. Holocene 17:481 - 494. http://dx.doi.org/10.1177/095968360 $\underline{7077027}$

Fortunato, A. B., A. Oliveira, E. T. Alves. 2002. Circulation and salinity intrusion in the Guadiana Estuary. Thalassas $18: 43-65$

Foundation for Environmental Education (FEE). 2006. Awards for improving the coastal environment: the example of the Blue Flag. Foundation for Environmantal Education. Denmark, pp. 34. 
Garel, E., L. Pinto, A. Santos, and O. Ferreira. 2009. Tidal and river discharge forcing upon water and sediment circulation at a rock-bound estuary (Guadiana Estuary, Portugal). Estuarine, Coastal and Shelf Science 84: 269-281. http://dx.d oi.org/10.1016/j.ecss.2009.07.002

Guimarães, M., C. Sousa, T. Garcia, T. Dentinho, and T. Boski. 2011. The value of improved water quality in Guadiana Estuary - a transborder application of contingent valuation methodology. Letters in Spatial and Resource Sciences.4: 31-48. http://dx.doi.org/10.1007/s12076-011-0052-1

Guimarães, M., C. Sousa, T. Boski, T. Dentinho. In press. Economic base model for Guadiana Estuary. An application for integrated coastal zone management. Marine Policy.

Hopkins, T. S., D. Bailly and J. Støttrup. 2011. A systems approach framework for coastal zones. Ecology and Society 16(4):25. http://dx.doi.org/10.5751/ES-04553-160425

Hoyt, H. 1939. The structure and growth of residential neighbourhoods in American cities. U.S. Government Printing Office, Washington, U.S.A. pp. 178.

Krakover, S. 2000. Partitioning seasonal employment in the hospitality industry. Tourism Management 21:461-471. URL: http://linkinghub.elsevier.com/retrieve/pii/S0261517799001016 http://dx.doi.org/10.1016/S0261-5177(99)00101-6

Lobo, J., F. Plaza, . R. Gonzáles, J. Dias, V. Kapsimalis, I. Mendes, and V. D. Rio. 2004. Estimations of bedload sediment transport in the Guadiana Estuary (SW Iberian Peninsula) during low river discharge periods. Journal of Coastal Research 12-26.

Madureira, L., T. Rambonilaza, I. Karpinski. 2007. Review of methods and evidence for economic valuation of agricultural non-commodity outputs and suggestions to facilitate its application to broader decisional contexts. Agriculture Ecosystems \& Environment 120:5-20. http://dx.doi.org/10.1016/ j.agee.2006.04.015

Marin, V., F. Palmisani, R. Ivaldi, R. Dursi, and M. Fabiano. 2009. Users' perception analysis for sustainable beach management in Italy. Ocean \& Coastal Management 52: 268-277. http://dx.doi.org/10.1016/j.ocecoaman.2009.02.001

McKenna, J., A. T. Williams, and J. A. G. Cooper. 2010. Blue Flag or Red Herring: Do beach awards encourage the public to visit beaches? Tourism Management 32 (3):576-588 http:// dx.doi.org/10.1016/j.tourman.2010.05.005

Metcalf and Eddy. Editors. 1995. Wastewater engineering: treatment and reuse. McGraw-Hill, New Delhi, India, pp. 1819.

Morais, P., M. A. Chicharo, and L. Chicharo. 2009. Changes in a temperate estuary during the filling of the biggest
European dam. Science of the Total Environment 407:2245-2259. http://dx.doi.org/10.1016/j.scitotenv.2008.11.037

North, D.C. 1955. Location theory and regional economic growth. Journal of Political Economy 63:243-258. URL: www.jstor.org/stable/1825076 http://dx.doi.org/10.1086/257668

Parrilla, J. C., A. R. Font, and J. R. Nadal. 2007. Accommodation determinants of seasonal patterns. Annals of Tourism Research 34:22-436. URL: http://dx.doi.org/10.1016/ j.annals.2006.10.002

Pennington, D. D. 2008. Cross-Disciplinary Collaboration and Learning. Ecology and Society 13 (2):8. [online]. URL: www .ecologyandsociety.org/vol13/iss2/art8

Ruiz Muñoz, F., M. L. González-Regalado Montero, and J. A. Morales González. 1996. Distribución y ecología de los foraminíferos y ostrácodos actuales del estuario mesomareal del río Guadiana (SO España). Geobios 29(5): 513-528.

Sampath, D. M. R., T. Boski, P. L. Silva, and F. A. Martins. 2011. Morphological evolution of the Guadiana Estuary and intertidal zone in response to projected sea-level rise and sediment supply scenarios. Journal of Quaternary Science 26 (2): 156-170. http://dx.doi.org/10.1002/jqs.1434

Santos, L. F. R. 1989. A Pesca do Atum no Algarve. Edição de autor com o apoio do Parque Natural da Ria Formosa, pp. 91.

Sousa, S. 2008. Modelo matemático de mortalidade de bactérias coliformes em águas costeiras. M.Sc. dissertation. Universidade Nova de Lisboa, pp. 67.

Tiebout, C. M. 1956. A pure theory of local public expenditures. Journal of Political Economy 64:416 http://dx. doi.org/10.1086/257839

Thiel, A. 2010. Constructing a strategic, national resource: European policies and the up-scaling of water services in the Algarve, Portugal. Environmental Management 46: 44-59. http://dx.doi.org/10.1007/s00267-010-9498-y

Trigo, R. M., D. Pozo-Vazquez, T. J. Osborn, Y. Castro-Diez, S. Gamiz-Fortis, and M. J.Esteban-Parra. 2004. North Atlantic oscillation influence on precipitation, river flow and water resources in the Iberian peninsula. International Journal of Climatology 24:925-944. http://dx.doi.org/10.1002/joc.1048

Videira, N., P. Antunes, and R. Santos. 2009. Scoping river basin management issues with participatory modelling: the Baixo Guadiana experience. Ecological Economics 68: 965-978. http://dx.doi.org/10.1016/j.ecolecon.2008.11.008

Wolanski, E., L. Chicharo, M. A. Chicharo, and P. Morais. 2006. An ecohydrology model of the Guadiana Estuary (South 
Portugal). Estuarine Coastal and Shelf Science 70:132-143.

URL: http://linkinghub.elsevier.com/retrieve/pii/S0272771406002447

http://dx.doi.org/10.1016/j.ecss.2006.05.029 